\title{
Inflammation in Coronary Artery Ectasia Compared to Atherosclerosis
}

\author{
Ertan Yetkin ${ }^{1}$ * , Selcuk Ozturk ${ }^{2}$ and Gulay Imadoglu Yetkin ${ }^{3}$ (D) \\ 1 Division of Cardiology, Private Yenisehir Hospital, Mersin 33100, Turkey \\ 2 Department of Cardiology, Ankara Research and Training Hospital, Ankara 06310, Turkey; \\ selcukozturk85@hotmail.com \\ 3 Division of Microbiology, International Medical Center IMC Hospital, Mersin 33100, Turkey; \\ gulayyetkin03@hotmail.com \\ * Correspondence: ertanyetkin@hotmail.com
}

Received: 25 August 2018; Accepted: 28 September 2018; Published: 29 September 2018

Dear Editor,

We have read with great enthusiasm the article recently published by Boles et al. [1]. Briefly, they compared the systemic immunoinflammatory status in patients with coronary artery ectasia (CAE) with the cytokine milieu in healthy control subjects and patients with coronary artery disease (CAD). CAE patients showed increased systemic levels of INF- $\gamma$, TNF- $\alpha$, IL-1 $\beta$, IL-6, and IL- 8 and lower IL-2 and IL-4 than control subjects and patients with CAD. They have also commented that these increased inflammatory responses are likely the result of macrophage-mediated cytokine production.

Although CAE has increasingly gained interest in the literature over the last decades, the pathophysiologic mechanism of CAE still remains to be elucidated. Frequent coexistence of CAE with CAD is the likely reason for the lack of knowledge regarding the exact mechanism of CAE. However, distinct differences between CAE and CAD have been documented in the literature in terms of clinical course and pathophysiologic steps and biomarkers [2-6]. The most promising difference is the increased inflammatory status in patients with CAE compared to those with normal coronary arteries and CAD, as demonstrated by Boles et al. Increased cellular activation molecules such as intercellular adhesion molecule (ICAM), vascular cell adhesion molecule (VCAM), E-selectin, $\mathrm{C}$-reactive protein, and activation markers of macrophages have already been documented as indicating increased inflammation in CAE compared to CAD [7-10]. What needs to be figured out is the underlying mechanism of increased inflammatory state in CAE. Regarding the main pathophysiologic mechanism of CAE, vascular wall abnormality or destruction is the key process of the disease. Albeit difficult to prove yet, vascular wall abnormality may originate from hereditary factors or infectious etiology resulting in improper extracellular matrix remodeling through an inflammatory process. So far, Boles et al. [1] has added another proof against atherosclerosis in the pathophysiology of CAE. Moreover, given the common coexistence of CAE with other arterial and venous aneurismal dilatations $[2,3,11]$, it is time to consider CAE as a manifestation of systemic vascular wall abnormalities rather than a localized disease of the heart. Likewise, Juvonen et al. [12] has already documented increased levels of IL-1 $\beta$, IL- 8 TNF- $\alpha$, and interferon-gamma in patients with abdominal aortic aneurysm, which is another example of a dilating vascular disease. In conclusion, coronary artery ectasia or its coexistence, namely, dilating vascular disease, should be investigated individually to figure out the main underlying mechanisms or etiologies rather than focusing on atherosclerosis itself.

Conflicts of Interest: The authors declare no conflict of interest. 


\section{References}

1. Boles, U.; Johansson, A.; Wiklund, U.; Sharif, Z.; David, S.; McGrory, S.; Henein, M.Y. Cytokine Disturbances in Coronary Artery Ectasia Do Not Support Atherosclerosis Pathogenesis. Int. J. Mol. Sci. 2018, $19,260$. [CrossRef] [PubMed]

2. Ozturk, S.; Yetkin, E.; Waltenberger, J. Molecular and cellular insights into the pathogenesis of coronary artery ectasia. Cardiovasc. Pathol. 2018, 35, 37-47. [CrossRef] [PubMed]

3. Yetkin, E.; Waltenberger, J. Novel insights into an old controversy: Is coronary artery ectasia a variant of coronaryatherosclerosis? Clin. Res. Cardiol. 2007, 96, 331-339. [CrossRef] [PubMed]

4. Yetkin, E.; Acikgoz, N.; Sivri, N.; Tekin, G.O.; Yagmur, J.; Aksoy, Y.; Turhan, H. Increased plasma levels of cystatin $\mathrm{C}$ and transforming growth factor-beta1 in patients with coronary artery ectasia: Can there be a potential interaction between cystatin C and transforming growth factor-beta1. Coron. Artery Dis. 2007, 18, 211-214. [CrossRef] [PubMed]

5. Turhan, H.; Yetkin, E. Coronary artery ectasia: Is it a destructive inflammatory lesion of the vascular wall? Int. J. Cardiol. 2007, 118, 241. [CrossRef] [PubMed]

6. Yetkin, E.; Acikgoz, N.; Aksoy, Y.; Bariskaner, E.; Sivri, N.; Akturk, E.; Turhan, H.; Kosar, F.; Cehreli, S. Decreased carotid intima-media thickness in patients with coronary artery ectasia compared with patients with coronary artery disease. Coron. Artery Dis. 2005, 16, 495-498. [CrossRef] [PubMed]

7. Turhan, H.; Erbay, A.R.; Yasar, A.S.; Aksoy, Y.; Bicer, A.; Yetkin, G.; Yetkin, E. Plasma soluble adhesion molecules; intercellular adhesion molecule-1, vascular cell adhesion molecule-1 and E-selectin levels in patients with isolated coronary artery ectasia. Coron. Artery Dis. 2005, 16, 45-50. [CrossRef] [PubMed]

8. Turhan, H.; Erbay, A.R.; Yasar, A.S.; Balci, M.; Bicer, A.; Yetkin, E. Comparison of C-reactive protein levels in patients with coronary artery ectasia versus patients with obstructive coronary artery disease. Am. J. Cardiol. 2004, 94, 1303-1306. [CrossRef] [PubMed]

9. Yildirim, N.; Tekin, I.O.; Dogan, S.M.; Aydin, M.; Gursurer, M.; Cam, F.; Gungorduk, A.; Akoz, A. Expression of monocyte and lymphocyte adhesion molecules is increased in isolated coronary artery ectasia. Coron. Artery Dis. 2007, 18, 49-53. [CrossRef] [PubMed]

10. Yildirim, N.; Tekin, I.O.; Arasli, M.; Aydin, M. Further increase in the expression of activation markers on monocyte-derived dendritic cells in coronary artery disease patients with ectasia compared to patients with coronary artery disease alone. Mediat. Inflamm. 2010, 2010, 748919. [CrossRef] [PubMed]

11. Yetkin, E.; Ozturk, S. Dilating Vascular Diseases: Pathophysiology and Clinical Aspects. Int J. Vasc. Med. 2018, 2018, 9024278. [CrossRef] [PubMed]

12. Juvonen, J.; Surcel, H.M.; Satta, J.; Teppo, A.M.; Bloigu, A.; Syrjälä, H.; Airaksinen, J.; Leinonen, M.; Saikku, P.; Juvonen, T. Elevated circulating levels of inflammatory cytokines in patients with abdominal aortic aneurysm. Arterioscler. Thromb. Vasc. Biol. 1997, 17, 2843-2847. [CrossRef] [PubMed]

(c) 2018 by the authors. Licensee MDPI, Basel, Switzerland. This article is an open access article distributed under the terms and conditions of the Creative Commons Attribution (CC BY) license (http:/ / creativecommons.org/licenses/by/4.0/). 